\title{
Encodable Activators of Src Family Kinases
}

\author{
Crystal D. Zellefrow, ${ }^{\ddagger}$ Jennifer S. Griffiths,${ }^{\S}$ Sarmistha Saha, ${ }^{\ddagger}$ Abby M. Hodges,${ }^{\S}$ Jessica L. \\ Goodman, ${ }^{\ddagger}$ Joshiawa Paulk, ${ }^{\S}$ Joshua A. Kritzer ${ }^{\S}$ and Alanna Schepartz ${ }^{\star, \&, \#}$ \\ Departments of ${ }^{\S}$ Chemistry, ${ }^{*}$ Molecular Biophysics and Biochemistry, and ${ }^{\#}$ Molecular, Cellular and \\ Developmental Biology, Yale University \\ New Haven, Connecticut 06520-8107
}

\section{Contents}

I. Peptide Synthesis and Purification
A. Table of peptide sequences
B. Peptide and miniature protein synthesis \& purification
C. Procedure used to prepare fluorescently labeled peptides and miniature proteins
D. Mass spectrometry data

II. Protein Expression and Purification
A. General information
B. Expression and purification of $\mathrm{SH3}$ domains
C. Expression and purification of Nef
D. Expression and purification of Hck kinase

III. Miniature Protein Characterization
A. Circular Dichroism
B. Analytical Ultracentrifugation
C. Fluorescence Polarization
D. Equilibrium dissociation constants $\left(K_{d}, \mu M\right)$ of miniature protein॰SH3 domain complexes
E. Kinase Activation Assay
F. Activation of Hck Kinase by Miniature Protein SH3 Domain-Ligands

IV. References cited 


\section{Peptide Synthesis and Purification.}

\section{A. Peptide Sequences}

$\begin{array}{ll}\text { Peptide } 1 & \text { APPLPPRNRPRL } \\ \text { PP1 } & \text { APPLPPRNPGDDAPVEDLIRFYDNLQQYLNVVTRHRY } \\ \text { PP2 } & \text { APPLPPRNRGDDAPVEDLIRFYDNLQQYLNVVTRHRY } \\ \text { PP3 } & \text { APPLPPRNRPRDAPVEDLIRFYDNLQQYLNVVTRHRY } \\ \text { YY1 } & \text { APPLPPRNPGEDASPEELSRYYASLRHYLNLVTRQRY } \\ \text { YY2 } & \text { APPLPPRNRGEDASPEELSRYYASLRHYLNLVTRQRY } \\ \text { HCk substrate } & \text { AEEEIYGEFEAKKKKG }\end{array}$

B. Peptide and miniature protein synthesis \& purification. Miniature proteins PP1, PP2, PP3, YY1, YY2, peptide 1 (this molecule is referred to as APP12 in reference ${ }^{1}$ ) and the Hck substrate peptide were synthesized using standard solid-phase Fmoc chemistry (25 $\mu$ mol scale) and a Symphony® multi-channel solid phase synthesizer (Protein Technologies, Inc., Tuscon, AZ). All $\alpha$-amino acids and NovaSyn TGR resin (cat. 01-64-0060) was purchased from Novabiochem. All miniature proteins were synthesized to contain free amines at their N-termini and carboxamides at their C-termini. With the exception of peptide 1, all miniature proteins or peptides employed in fluorescence polarization (FP) assays contained an additional cysteine residue at the C-terminus which was labeled as described below. The fluorescently labeled analog of peptide $1\left({ }^{\mathrm{Flu}} \mathbf{1}\right)$ contained an additional cys-gly-gly sequence at the N-terminus and lacked the C-terminal leu.

Crude peptides were purified by reverse-phase HPLC using a Waters instrument equipped with a 1525EF binary pump and 2996 photo-diode array detector and was operated using the 
Empower software suite. Samples were purified using Grace Vydac C8 or C18 preparative scale columns ( $300 \AA$ silica, $10 \mu \mathrm{m}$ particle size, $22 \mathrm{~mm} \times 250 \mathrm{~mm}$ ) and water/acetonitrile gradients containing $0.1 \%$ TFA. Peptide identity was verified by mass spectrometry using an Applied Biosystems Voyager-DE Pro MALDI-TOF mass spectrometer (Foster City, CA). Peptide purity was confirmed by re-injection of a purified sample on a Vydac analytical C 8 column ( $300 \AA$ silica, $5 \mu \mathrm{M}$ particle size, $4.6 \mathrm{~mm} \times 150 \mathrm{~mm}$ ). Peptide concentration and identity were also confirmed by amino acid analysis at the HHMI Biopolymer/Keck Foundation Biotechnology Resource Laboratory at the Yale University School of Medicine. Once purified, miniature proteins were lyophilized to dryness, brought up in water and stored at $-20{ }^{\circ} \mathrm{C}$.

C. Preparation of fluorescently labeled peptides and miniature proteins. Miniature proteins or peptides were labeled using 5-iodoacetamidofluorescein (Molecular Probes). A typical reaction contained $\sim 5 \mathrm{mg}$ HPLC purified miniature protein or peptide and 10 equiv 5iodoacetamidofluorescein in a 1:1 mixture of $10 \mathrm{mM}$ sodium phosphate $(\mathrm{pH} 8)$ and DMSO. Labeling reactions were incubated with rotation for $3 \mathrm{~h}$ at room temperature or $\sim 10 \mathrm{~h}$ at $4{ }^{\circ} \mathrm{C}$. Labeled product was purified by reverse-phase HPLC and its identity verified by MALDI-TOF and amino acid analysis as described above. After purification, all fluorescently labeled miniature proteins were lyophilized, brought up in water and stored at $-20{ }^{\circ} \mathrm{C}$ protected from light.

\section{Table S1. Mass spectrometry data}




\begin{tabular}{|c|c|c|}
\hline & Calculated Mass (Da) & Observed Mass (Da) \\
\hline Peptide 1 & 1383.7 & 1383.7 \\
\hline PP1 & 4350.8 & 4354.5 \\
\hline PP2 & 4410.0 & 4417.0 \\
\hline PP3 & 4491.2 & 4495.0 \\
\hline YY1 & 4327.8 & 4328.6 \\
\hline YY2 & 4386.9 & 4386.8 \\
\hline Flu1 $^{1}$ & 1874 & 1880.38 \\
\hline PP1 $^{\text {Flu }}$ & 4839.36 & 4846.5 \\
\hline PP2 $^{\text {Flu }}$ & 4901.46 & 4910.0 \\
\hline PP3 $^{\text {Flu }}$ & 4982.66 & 4993.7 \\
\hline YY1 $^{\text {Flu }}$ & 4818.4 & 4826.1 \\
\hline YY2 $^{\text {Flu }}$ & 4878.4 & 4882.2 \\
\hline Hck Substrate $^{\text {Slu }}$ & 1856.06 & 1856.5 \\
\hline & & \\
\hline
\end{tabular}

\section{Protein Expression and Purification}

A. General Information. The pGEX-4T-1 plasmids ${ }^{2}$ used to over-express the SH3 domainGST fusion proteins of human Hck (residues 77-137 of full-length kinase), human Fyn (residues 81-142) and human Lyn (residues 62-122) were obtained from Dr. Wendell Lim (UCSF); the pGEX-2T plasmid $^{3}$ used to over-express the chicken c-Src (residues 81-140) SH3 domain-GST fusion protein was obtained from Dr. Stuart Schreiber (Broad Institute); and the pGEX-3Xb plasmid $^{4}$ used to express the human Lck (residues 62-128) SH3 domain-GST fusion was from 
Dr. Philip Cole (Johns Hopkins). The Hck and Csk baculovirus and the Nef-GST fusion pGEX construct were kind gifts from Dr. W. Todd Miller (SUNY-Stonybrook). The c-Src SH3 $3^{\mathrm{P} 133 \mathrm{~L}}$ variant was prepared using QuikChange ${ }^{\circledR}$ site-directed mutagenesis of the c-Src construct mentioned above; its sequence was verified by DNA sequencing at the W.M. Keck Foundation Biotechnology Resource Laboratory at the Yale University School of Medicine.

B. Expression and purification of SH3 domains. Plasmids were transformed into BL21(DE3) E. coli cells (Stratagene) and a single colony was used to inoculate a $500 \mathrm{~mL}$ culture in LB media supplemented with $50 \mu \mathrm{g} / \mathrm{mL}$ carbenicillin. The culture was incubated at $37^{\circ} \mathrm{C}$ with shaking at $\sim 250 \mathrm{rpm}$ until the solution reached an optical density at $600 \mathrm{~nm}\left(\mathrm{OD}_{600}\right)$ of $\sim 0.8$ absorbance units. Isopropyl $\beta$-D-galactoside (IPTG) was added to a final concentration of 0.5 $\mathrm{mM}$ and the incubation continued for another $\sim 5 \mathrm{~h}$ at $37^{\circ} \mathrm{C}$ with shaking. Cells were harvested by centrifugation at $2,700 \times g$ and the resulting cell pellet was flash-frozen. The pellet was then thawed, resuspended in $30 \mathrm{~mL}$ PBS $\left(1 \mathrm{mM} \mathrm{KH}_{2} \mathrm{PO}_{4}, 155 \mathrm{mM} \mathrm{NaCl}, 3 \mathrm{mM} \mathrm{Na}_{2} \mathrm{HPO}_{4}(\mathrm{pH}\right.$ 7.4)) and the cells lysed ( 2 passes) using a French ${ }^{\circledR}$ Pressure Cell Press (SLM Instruments, Inc) with the Sim Aminco french pressure cell (cat. \# FA-073). Phenylmethylsulfonylfluoride (PMSF, final concentration $1 \mathrm{mM}$ ) was added to the suspension immediately before lysis. The cell lysate was cleared by centrifugation at $21,000 \times g$ and the supernatant incubated with pre-equilibrated Glutathione Sepharose 4B (Amersham Pharmacia; $4 \mathrm{~mL}$ resin per $500 \mathrm{~mL}$ cell culture) overnight at $4{ }^{\circ} \mathrm{C}$ with end-over-end rotation. The fusion protein was eluted from the resin using $4 \times 1 \mathrm{~mL}$ of Elution Buffer (10 mM glutathione, $50 \mathrm{mM}$ Tris ( $\mathrm{pH} 8.0)$ ). The purity of the fractions was assessed by SDS PAGE; pure fractions were pooled and the resulting solution was dialyzed at 4 ${ }^{\circ} \mathrm{C}$ using Slide-a-Lyzers ${ }^{\circledR}$ dialysis cassettes (cat. \# 66425, Pierce) against PBS buffer 
supplemented with dithiothreitol (DTT, $1 \mathrm{mM}$ final concentration). Stocks of SH3 domain-GST fusion proteins used in fluorescence polarization assays $(100-200 \mu \mathrm{M})$ were separated into aliquots, flash-frozen and stored at $-20{ }^{\circ} \mathrm{C}$. The concentrations of all SH3 domain-GST fusion proteins were determined by amino acid analysis as described above.

C. Expression and purification of Nef. The HIV Nef protein employed as a positive control for the Hck activation assay ${ }^{5}$ was expressed in BL21 (DE3) cells as a GST fusion. ${ }^{6}$ Transformed cells were grown in LB supplemented with $50 \mu \mathrm{g} / \mathrm{mL}$ carbenicillin $(1 \mathrm{~L})$ at $37^{\circ} \mathrm{C}$ to $\mathrm{OD}_{600}=0.7$, induced at $25^{\circ} \mathrm{C}$ with $0.5 \mathrm{mM} \mathrm{IPTG}$ and incubated for approximately $22 \mathrm{~h}$. The cells were pelleted $(4000 \times \mathrm{g}, 10 \mathrm{~min})$, resuspended in $30 \mathrm{~mL}$ PBS $\left(1 \mathrm{mM} \mathrm{KH} \mathrm{PO}_{4}, 155 \mathrm{mM}\right.$ $\mathrm{NaCl}, 3 \mathrm{mM} \mathrm{Na}_{2} \mathrm{HPO}_{4}(\mathrm{pH}$ 7.4)) supplemented with $1 \mathrm{mM} \mathrm{DTT}, 1 \mathrm{mM}$ PMSF and 1 tablet Roche EDTA-free protease inhibitor (cat \# 11873580001, 1 tablet per $30 \mathrm{~mL}$ or 1 mini-tablet per $10 \mathrm{~mL}$ volume) and lysed using a French Press as described above. The cell lysate was cleared by centrifugation $(10,000 \times \mathrm{g}, 30 \mathrm{~min})$ and the supernatant was incubated at $4{ }^{\circ} \mathrm{C}$ with Glutathione Sepharose 4B resin $(2 \mathrm{~mL}$ per $1 \mathrm{~L}$ cell culture, $1 \mathrm{~h})$ pre-equilibrated with PBS. The resin was washed with PBS containing $1 \mathrm{mM}$ DTT $(20 \mathrm{~mL})$ and the fusion protein cleaved while resin-bound with $100 \mathrm{U}$ thrombin (Amersham Pharmacia) for $16 \mathrm{~h}$ according to the manufacturer's protocol. Nef was eluted with PBS $(1 \mathrm{~mL})$ and the buffer was exchanged using a NAP-25 column (cat \# 17-0852-01, Amersham Pharmacia) equilibrated with Nef IE Buffer (20 mM Tris (pH 7.0), $50 \mathrm{mM} \mathrm{KCl,} 1 \mathrm{mM}$ PMSF, $1 \mathrm{mM} \mathrm{DTT}$ ). To separate Nef from thrombin, the dialyzed sample $(3.5 \mathrm{~mL})$ was loaded onto a $5 \mathrm{~mL}$ HiTrap Q XL ion exchange column (Amersham Pharmacia) that had been pre-equilibrated with Nef IE Buffer and eluted with a linear $\mathrm{NaCl}$ gradient $(0-1.0 \mathrm{M})$ using the $\mathrm{AKTA}{ }^{\mathrm{TM}}$ FPLC with Unicorn 5.01 software 
(Amersham Biosciences Corp.). Fractions containing Nef were identified by SDS-PAGE, pooled, the buffer exchanged into Nef Freeze Buffer (20 mM Tris, pH 8.5, $50 \mathrm{mM} \mathrm{KCl,} 1 \mathrm{mM}$ DTT, 1 mM PMSF, 10\% glycerol) as described above, separated into aliquots and stored at -20 ${ }^{\circ} \mathrm{C}$.

D. Expression and purification of Hck. Down-regulated Hck kinase (containing an Nterminal $\mathrm{His}_{6}$ tag) has been co-expressed previously with Csk in Sf9 cells. ${ }^{7}$ We chose to use HighFive cells (Invitrogen), which are reported to support higher protein expression levels. ${ }^{8}$ The procedure described below typically produced $0.5 \mathrm{mg}$ purified recombinant protein from a 50 mL HighFive culture. All buffers used for Hck purification contained 1 mM PMSF and Roche EDTA-free protease inhibitor cocktail tablets. HighFive cells were grown in suspension $(50 \mathrm{~mL})$ in Express Five serum-free media (cat \# 10486-025, Gibco) supplemented with $20 \mathrm{mM}$ glutamine and $10 \mu \mathrm{g} / \mathrm{mL}$ Gentamycin to a density of $2.0 \times 10^{6}$ cells $/ \mathrm{mL}$ and infected with Hck and Csk baculovirus at multiplicity of infection of 5. Cells were harvested by centrifugation after $48 \mathrm{~h}(800 \times \mathrm{g}, 10 \mathrm{~min})$ and stored at $-20^{\circ} \mathrm{C}$. The cell pellet was thawed and resuspended in $7.5 \mathrm{~mL}$ HisLysis buffer (20 mM Tris ( $\mathrm{pH} 8.5$ ), $150 \mathrm{mM} \mathrm{KCl,} 0.01 \% \beta$-mercaptoethanol, $0.04 \%$ NP40, $10 \mathrm{mM}$ imidazole, 5\% glycerol). Triton X-100 (1\%) was added and the cells lysed by end-over-end rotation for 15 minutes at $4{ }^{\circ} \mathrm{C}$. The lysate was cleared by centrifugation $(100,000$ $\times g$ ) for $1 \mathrm{~h}$ and the supernatant added to $0.5 \mathrm{~mL}$ Ni-NTA resin, washed with $20 \mathrm{~mL}$ HisBuffer A (20 mM Tris, $500 \mathrm{mM} \mathrm{KCl,} \mathrm{0.04 \%} \beta$-mercaptoethanol, 0.01\% NP40, $20 \mathrm{mM}$ imidazole, 5\% glycerol $(\mathrm{pH} 8.5)$ and incubated with end-over-end rotation for $1 \mathrm{~h}$ at $4{ }^{\circ} \mathrm{C}$. The resin was transferred to an empty PD10 column, drained and washed successively with $10 \mathrm{~mL}$ of HisBuffer A, $2.5 \mathrm{~mL}$ HisBuffer B (20 mM Tris, $1 \mathrm{M} \mathrm{KCl,} \mathrm{0.04 \%} \beta$-mercaptoethanol, $0.01 \%$ 
NP40, 5\% glycerol (pH 8.5)), $1 \mathrm{~mL}$ HisBuffer A and the protein eluted with $8 \times 1 \mathrm{~mL}$ washes with HisElution buffer (20 mM Tris, $150 \mathrm{mM} \mathrm{KCl,} \mathrm{0.04 \%} \beta$-mercaptoethanol, 0.01\% NP40, 100 $\mathrm{mM}$ imidazole, $5 \%$ glycerol ( $\mathrm{pH} 8.5)$ ). Each wash was incubated for 1 min with the resin before collection. The fractions containing Hck were identified by SDS-PAGE, pooled, concentrated (Amicon Ultra-4 Centrifugal Filter Device, 10k MWCO, cat \# UFC801024, Millipore) to $1 \mathrm{~mL}$ (approximately $0.6 \mathrm{mg} / \mathrm{mL}$ ) and dialyzed against Hck Freeze Buffer (20 mM Tris (pH 8.5), 50 $\mathrm{mM} \mathrm{NaCl}, 3 \mathrm{mM}$ DTT, $10 \%$ glycerol, $2 \times 500 \mathrm{~mL}$ ). The enzyme was aliquoted, flash-frozen and stored at $-20{ }^{\circ} \mathrm{C}$.

\section{Miniature protein characterization}

A. Circular Dichroism. Circular dichroism spectra were measured using a Jasco J-810150S Spectropolarimeter and Spectra Manager software v.1.53.01. Spectra were acquired at miniature protein concentrations of 5-20 $\mu \mathrm{M}$ in $10 \mathrm{mM}$ sodium phosphate buffer (pH 7.4). Prior to analysis samples were spun $16,000 \times g$ for 10 minutes to ensure no particulates were transferred to the sample cuvette. Wavelength scans from $190 \mathrm{~nm}$ to $260 \mathrm{~nm}$ (data pitch $0.5 \mathrm{~nm}$, scan speed $50 \mathrm{~nm} / \mathrm{min}, 4 \mathrm{sec}, 1 \mathrm{~nm}$ bandwidth and 3 accumulations) were taken every $10{ }^{\circ} \mathrm{C}$ as the sample temperature was raised from $4{ }^{\circ} \mathrm{C}$ to $84{ }^{\circ} \mathrm{C}$ using the variable temperature module. Simultaneously, the $\Theta$ readings were measured at $222 \mathrm{~nm}$ during the thermal denaturation (data pitch $0.5{ }^{\circ} \mathrm{C}, 5$ second delay, temperature slope $1^{\circ} \mathrm{C} / \mathrm{min}, 4 \mathrm{sec}$ response, $1 \mathrm{~nm}$ bandwidth, continuous scan mode). The sample was cooled back to $4{ }^{\circ} \mathrm{C}$ for another wavelength scan to verify that the melting transitions were reversible. Mean residue ellipticity values were calculated from the equation MRE $=\left(\Theta_{\text {sample }}-\Theta_{\text {buffer }}\right) /(L \times c \times n \times 1000)$, where $\Theta$ is observed signal 
in millidegrees, $L$ is the length of the cuvette, $c$ is the concentration of peptide in $\mathrm{dmol} / \mathrm{cm}^{3}$ and $n$ is the number of amino acid residues in the molecule. The melting temperature $\left(\mathrm{T}_{\mathrm{M}}\right)$ was estimated by the inflection point of the melt shown in Figure S1. They were $\sim 50{ }^{\circ} \mathrm{C}$ and $\sim 25^{\circ} \mathrm{C}$ for YY1 and YY2, respectively.

Figure S1. Temperature dependent circular dichroism spectra of miniature proteins (A) YY1

$(25 \mu \mathrm{M})$ and $(\mathrm{B}) \mathrm{YY} 2(20 \mu \mathrm{M})$ in $10 \mathrm{mM}$ sodium phosphate buffer ( $\mathrm{pH}$ 7.4).
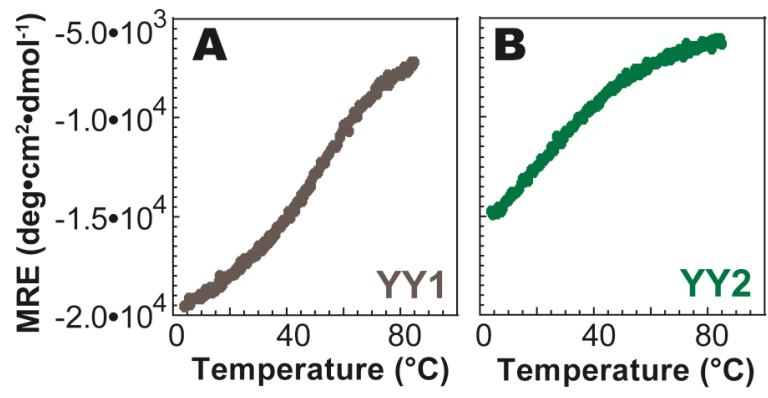

B. Sedimentation Equilibrium. Analytical ultracentrifugation was performed using a Beckman Coulter Proteome Lab XL-I Protein Characterization System equipped with an AN 60Ti 4-hole rotor and six-channel, carbon-epoxy composite centerpieces (Beckman). A stock of YY1 $(1 \mathrm{~mL}, \sim 500 \mu \mathrm{M})$ was dialyzed against $2 \times 1 \mathrm{~L}$ dialysis buffer $\left(1 \mathrm{mM} \mathrm{KH}_{2} \mathrm{PO}_{4}, 155 \mathrm{mM}\right.$ $\mathrm{NaCl}, 3 \mathrm{mM} \mathrm{Na}_{2} \mathrm{HPO}_{4}(\mathrm{pH}$ 7.4)) to remove residual TFA. The dialyzed peptide was separated into aliquots and diluted with dialysis buffer to prepare samples at $35.5 \mu \mathrm{M}, 75 \mu \mathrm{M}$, and $142 \mu \mathrm{M}$ concentrations, which were then centrifuged at 42,000 and 50,000 rpm. Temperature was maintained during centrifugation at $25^{\circ} \mathrm{C}$ and the absorbance was read at $280 \mathrm{~nm}$ with $0.01 \mathrm{~cm}$ step size. The Match module of the Heteroanalysis software v1.1.19, which monitors radial concentration gradients, was used to determine when equilibrium had been established. The partial specific volume $(\bar{v})$ of the miniature proteins was calculated from amino acid composition using the Sedimentation Interpretation Program "Sednterp" software v1.08. The data was first fit to an equation describing the sedimentation of an ideal species of molecular 
weight $M_{n}$ (equation 1) using Heteroanalysis software v1.1.19:

Equation 1. $C(r)=C\left(r^{0}\right) \exp \frac{(1-\bar{v} \rho) M_{n} \varpi^{2}}{2 R T}\left(r^{2}-r_{0}^{2}\right)$

In this equation, $C$ represents the concentration (any unit) of the sedimenting species at radial positions $r$ and $r_{0} \mathrm{~cm}$ from the center of rotation; $\bar{v}$ is the partial specific volume of the sedimenting species in $\mathrm{cc} / \mathrm{gm} ; \rho$ is the density of the supporting buffer in $\mathrm{g} / \mathrm{cc} ; \omega$ is the angular velocity of the rotor (radians/s); $M_{n}$ is the "molar" molecular weight of sedimenting species ( $\mathrm{g} / \mathrm{mol}) ; M_{b}$ is the "buoyant" molecular weight, equal to $M_{n}(1-\bar{v} \rho) ; R$ is the universal gas constant $\left(8.315 \times 10^{7} \mathrm{ergs} \bullet \mathrm{K}^{-1} \cdot \mathrm{mol}^{-1}\right)$ and $T$ is the temperature in Kelvin.

The best fit of the AU data for YY1 to equation 1 indicated a molecular weight of 5,968 Da, significantly higher than the calculated monomer molecular weight (4,327 Da), suggesting selfassociation of YY1 at these concentrations. The data was next fit to an equation describing sedimentation of a species in a monomer- $n$-mer equilibrium (equation 2 ). The best fit of the AU data to this equation yielded a stoichiometry of $n=1.985[1.758,2.226]$ (two standard deviations calculated using f-statistics) with an $\ln K_{A}=8.624$ [8.496, 8.753]. This value corresponds to a equilibrium dissociation constant $\left(K_{D}\right)$ of $180 \mu \mathrm{M}$. Thus YY1 is approximately $80 \%$ monomeric at $25 \mu \mathrm{M}$ concentration in PBS ( $\mathrm{pH} 7.4)$.

\section{Equation 2.}

$C(r)_{\text {tot }}=C\left(r^{0}\right)_{\text {monomer }} \exp \frac{(1-\bar{v} \rho) M_{n} \varpi^{2}}{2 R T}\left(r^{2}-r_{0}^{2}\right)+C\left(r^{0}\right)_{n-m e r} \exp \frac{(1-\bar{v} \rho) n M_{n} \varpi^{2}}{2 R T}\left(r^{2}-r_{0}^{2}\right)$ 

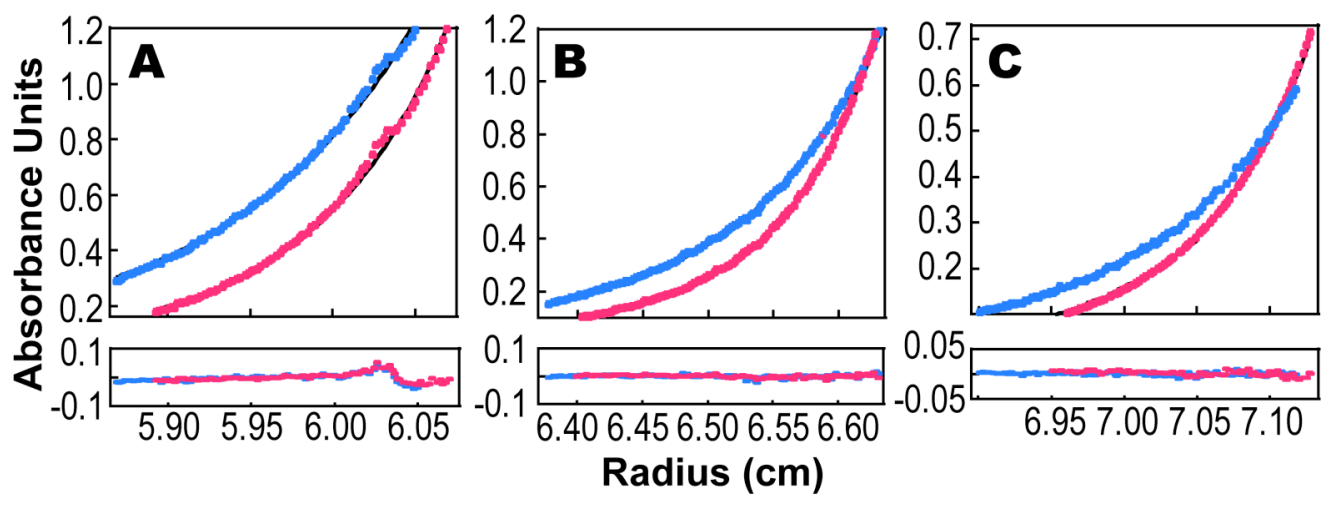

Figure S2.

Sedimentation

equilibrium

analysis of YY1 at

(A) $141 \mu \mathrm{M}$; (B)

$72 \mu \mathrm{M}$; and (C)

$35.5 \mu \mathrm{M}$ concentration at 42,000 (blue) and 50,000 (red) rpm.

C. Fluorescence Polarization. Fluorescence polarization assays were performed with $50 \mathrm{nM}$ fluorescently labeled miniature protein and the indicated SH3 domain-GST fusion protein in PBS (1 $\mathrm{mM} \mathrm{KH}_{2} \mathrm{PO}_{4}, 155 \mathrm{mM} \mathrm{NaCl}, 3 \mathrm{mM} \mathrm{Na}_{2} \mathrm{HPO}_{4}(\mathrm{pH} 7.4)$ ) supplemented with $1 \mathrm{mM}$ DTT and using the Analyst ${ }^{\mathrm{TM}}$ AD 96•384 automated fluorescence plate reader (LjL Biosystems). Binding reactions $(32 \mu \mathrm{L})$ were analyzed within 384-well assay plates (Corning Inc., Plate \#3654) using settings defined by Criterion Host software v.2.00.11 and z height $1 \mathrm{~mm}$. Polarization was measured by excitation with vertically polarized light at $485 \mathrm{~nm}$ and the fluorescence emission detected at $530 \mathrm{~nm}$ in both the vertical and horizontal directions. An average of five measurements were recorded for each well. Samples were equilibrated at room temperature for 25 min before analysis, a time sufficient for the binding reactions to reach equilibrium. The polarization data were fit using Kaleidagraph v3.6 software to equation 3, which is derived from first principles without assumptions.

Equation 3. $P_{\mathrm{obs}}=P_{\min }+\left(\left(P_{\max }-P_{\min }\right) /\left(2\left[\right.\right.\right.$ peptide $\left.\left.\left.^{\mathrm{Flu}}\right]\right)\right)\left(\left[\right.\right.$ peptide $\left.{ }^{\mathrm{Flu}}\right]+[$ target protein $]+K_{\mathrm{d}}-$ $\left.\left(\left(\left[\text { peptide }^{\mathrm{Flu}}\right]+[\text { target protein }]+K_{\mathrm{d}}\right)^{2}-4\left[\text { peptide }^{\mathrm{Flu}}\right][\text { target protein }]\right)^{0.5}\right)$ 
In this equation, $P_{\mathrm{obs}}$ is the observed polarization value at any given concentration of target protein (GST•SH3 domain). $P_{\min }$ is the polarization of peptide ${ }^{\mathrm{Flu}}$ at $50 \mathrm{nM}$ in the absence of target protein. $P_{\max }$ is the maximum polarization of peptide ${ }^{\mathrm{Flu}}$ at saturation with target protein. $K_{\mathrm{d}}$ is the equilibrium dissociation constant. In the case of several miniature protein $\bullet \mathrm{SH} 3$ domain pairs the binding curve did not reach saturation. In these cases a lower limit $K_{\mathrm{d}}$ was estimated by setting $P_{\max }$ equal to the observed polarization at the highest target protein concentration tested, which was often limited by solubility. The observed binding free energy, $\Delta \mathrm{G}$, was calculated from the relationship $\Delta \mathrm{G}=-R T \ln K_{\mathrm{d}}^{-1}$, where $R$ is the universal gas constant $\left(1.987 \times 10^{-3}\right.$ $\mathrm{kcal} \cdot \mathrm{mol}^{-1} \cdot \mathrm{K}^{-1}$ ) and $T$ is the temperature in Kelvin $(298 \mathrm{~K})$. Fluorescence polarization analysis of the binding of fluorescently labeled miniature proteins and peptide 1 to c-Src SH3 ${ }^{\mathrm{P} 133 \mathrm{~L}}$ are shown in Figure S3.

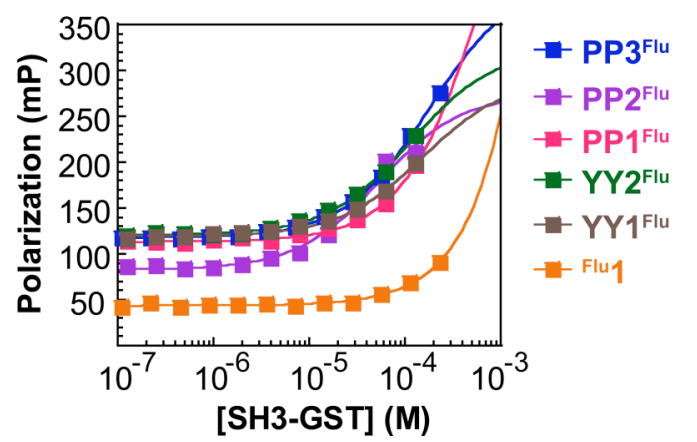

Figure S3. Fluorescence polarization analysis of the binding of $\mathrm{c}-\mathrm{Src} \mathrm{SH} 3^{\mathrm{P} 133 \mathrm{~L}}$ to fluorescently labeled miniature proteins or peptide $\mathbf{1}(50 \mathrm{nM})$. Free fits are shown. $K_{\mathrm{d}}$ values were estimated as described.

Control experiments indicated that none of the fluorescently labeled miniature proteins or peptides used in this work bound detectably to GST (all $K_{\mathrm{d}}$ 's $>100 \mu \mathrm{M}$ ). In several cases, the plots of polarization versus [SH3 domain] began to increase at high [SH3 domain] ( $>50 \mu \mathrm{M})$, perhaps because of a second binding event. In these cases (indicated by an asterisk (*) in Table S2), data above $50 \mu \mathrm{M}$ target protein was excluded during the curve fits. 
D. Table S2. Equilibrium dissociation constants $\left(K_{\mathrm{d}}, \mu \mathrm{M}\right)$ of miniature protein $\bullet \mathrm{SH} 3$ domain complexes

\begin{tabular}{|c|c|c|c|c|c|c|}
\hline & c-Src & Fyn & Hck & Lyn & Lck & c-Src $^{\text {P133L }}$ \\
\hline${ }^{\text {Flu } 1}$ & $1.5 \pm 0.1$ & $1.4 \pm 0.2$ & $1.6 \pm 0.2$ & $2.0 \pm 0.3$ & $>20$ & $>100$ \\
\hline PP1 $^{\text {Flu }}$ & $3.68 \pm 0.06$ & $25 \pm 2$ & $3.8 \pm 0.2$ & $4.9 \pm 0.9$ & $40 \pm 3$ & $>55$ \\
\hline PP2 $^{\text {Flu }}$ & $1.3 \pm 0.2$ & $14 \pm 3$ & $1.3 \pm 0.2$ & $3.7 \pm 0.9$ & $2.7 \pm 0.3$ & $>24$ \\
\hline PP3 $^{\text {Flu }}$ & $0.35 \pm 0.04^{*}$ & $2.1 \pm 0.3$ & $0.88 \pm 0.06^{*}$ & $1.8 \pm 0.3^{*}$ & $1.43 \pm 0.08$ & $>60$ \\
\hline YY1 $^{\text {Flu }}$ & $6.8 \pm 0.3$ & $15 \pm 2$ & $1.6 \pm 0.1$ & $1.58 \pm 0.02$ & $23 \pm 1$ & $>45$ \\
\hline YY2 $^{\text {Flu }}$ & $1.12 \pm 0.05$ & $7.1 \pm 1.8$ & $1.24 \pm 0.05$ & $1.55 \pm 0.04$ & $5.7 \pm 1.4$ & $>45$ \\
\hline
\end{tabular}

E. Kinase activation assay. Activation of Hck kinase was measured using a validated NADHcoupled assay as described. ${ }^{9}$ Briefly, purified Hck kinase $(15 \mu \mathrm{M})$ was first pre-incubated with $500 \mu \mathrm{M}$ ATP and $20 \mathrm{mM} \mathrm{MgCl}_{2}$ for $\sim 30 \mathrm{~min}$ on ice to initiate autophosphorylation of $\mathrm{Y}_{416} .^{2}$ The autophosphorylated product ( $0.55 \mu \mathrm{M}$ final concentration) was then incubated in Hck Reaction Buffer (20 mM MgCl $2,0.1 \mathrm{mM}$ DTT, $20 \mu \mathrm{g} / \mathrm{mL}$ BSA, $100 \mathrm{mM}$ HEPES (pH 7.5)) for 10 min at room temperature with the indicated concentration of Nef or miniature protein. At this time the remaining assay components ( $1 \mathrm{mM}$ PEP, $0.2 \mathrm{mM}$ NADH, $6 \mathrm{U}$ pyruvate kinase (Type II from rabbit muscle, Sigma), 6 U L-lactic dehydrogenase (Type II from rabbit muscle, Sigma), $600 \mu \mathrm{M}$ substrate peptide, and $500 \mu \mathrm{M}$ ATP) were added to initiate the reaction (total volume $200 \mu \mathrm{L}$ ) and the absorbance at $340 \mathrm{~nm}$ was monitored every $10 \mathrm{sec}$ for 10 min using a Beckman DU $730 \mathrm{UV} /$ Vis Spectrophotomer. The activation constant $K_{\text {act }}$ for each ligand was calculated from the initial rate as a function of ligand concentration as previously described, ${ }^{2}$ using equation 
4. Fold activation was calculated by dividing the rate in the presence of ligand by the rate in the absence of ligand.

Equation 4. $v_{a}=V_{a c t}[L] /\left(K_{a c t}+[L]\right)$

In this equation $v_{\mathrm{a}}$ is velocity measured in the presence of ligand minus the velocity measured in its absence; $V_{\text {act }}$ is the maximal activated velocity minus the velocity measured in the absence of ligand; $[L]$ is the concentration of activator and $K_{\text {act }}$ is concentration of activator at half-maximal activation.

F. Table S3. Activation of Hck kinase by miniature proteins and peptide $\mathbf{1}$

\begin{tabular}{|c|c|c|}
\hline Activator (50 $\boldsymbol{\mu M})$ & Activity $\left(\mathbf{n m o l} \cdot \mathbf{s e c}^{-1}\right)$ & Fold-Activation \\
\hline none & $10.9 \pm 4.6$ & $1 \pm 6$ \\
\hline peptide 1 & $33.9 \pm 3.2$ & $8 \pm 3$ \\
\hline PP1 & $83.6 \pm 6.0$ & $13 \pm 5$ \\
\hline PP2 & $138.8 \pm 7.6$ & $7 \pm 3$ \\
\hline PP3 & $83.9 \pm 5.4$ & $3 \pm 1$ \\
\hline YY1 & $34.1 \pm 1.7$ & $10 \pm 4$ \\
\hline YY2 & $114.7 \pm 7.7$ & $21 \pm 1$ \\
\hline Nef & $231.7 \pm 6.0$ & \\
\hline
\end{tabular}




\section{References cited}

(1) Feng, S.; Kasahara, C.; Rickles, R. J. and Schreiber, S. L. Proc Natl Acad Sci U S A 1995, 92, 12408-15.

(2) Nguyen, J. T.; Porter, M.; Amoui, M.; Miller, W. T.; Zuckermann, R. N. and Lim, W. A. Chem Biol 2000, 7, 463-473.

(3) Yu, H.; Rosen, M. K.; Shin, T. B.; Seidel-Dugan, C.; Brugge, J. S. and Schreiber, S. L. Science 1992, 258, 1665-1668.

(4) Sondhi, D. and Cole, P. A. Biochemistry 1999, 38, 11147-11155.

(5) Moarefi, I.; LaFevreBernt, M.; Sicheri, F.; Huse, M.; Lee, C. H.; Kuriyan, J. and Miller, W. T. Nature 1997, 385, 650-653.

(6) Lee, C. H.; Leung, B.; Lemmon, M. A.; Zheng, J.; Cowburn, D.; Kuriyan, J. and Saksela, K. EMBO J. 1995, 14, 5006-5015.

(7) Sicheri, F.; Moarefi, I. and Kuriyan, J. Nature 1997, 385, 602-609.

(8) Krupenko, S. A.; Horstman, D. A.; Wagner, C. and Cook, R. J. Protein Expression and Purification 1995, 6, 457-464.

(9) Barker, S. C.; Kassel, D. B.; Weigl, D.; Huang, X. Y.; Luther, M. A. and Knight, W. B. Biochemistry 1995, 34, 14843-14851. 